\title{
Adjustable sutures in strabismus surgery: why surgeons either love them or hate them after three decades
}

\author{
Suturas ajustáveis em cirurgia de estrabismo: por que os cirurgiões ou amam ou odeiam esta técnica \\ depois de três décadas
}

Galton C. Vasconcelos ${ }^{1}$, David L. Guyton ${ }^{2}$

\begin{abstract}
Strabismus surgeons continually seek to achieve the best results from their surgery, which means stable motor alignment and sensory improvement with a minimum number of procedures ${ }^{(1)}$. But the tables and algorithms that we employ for the number of muscles to be included in the surgery, and for the doses of surgery, are often not appropriate for difficult or unpredictable cases $^{(2)}$. The ability to modify the site of the muscle insertion on the globe to refine surgical results and to control postoperative deviations led Arthur Jampolsky to reintroduce an adjustable suture technique, almost four decades ago, based on the ideas of Bielschowsky, O'Connor, and $\mathrm{Harms}^{(3-6)}$. Common indications for adjustable sutures include paralysis, restrictive strabismus, and reoperations. A few surgeons use them in practically all cases, in children as well as in adults ${ }^{(7)}$.

Although the adjustable suture technique has been used for over 30 years, and there is a large volume of literature on the subject, randomized controlled trials have not been done ${ }^{(8)}$. Strabismus surgeons tend to be sharply polarized regarding their attitude toward adjustable sutures; they either love them and employ them often, as we do, or hate them and never employ them, claiming that equivalent results can be easily obtained without their use.

Proponents of adjustable sutures cite better results, less stress, and better patient and surgeon confidence and satisfaction. Detractors of adjustable sutures cite equivalent results, more stress, extra time involved, higher cost, and patient discomfort. The different stress levels undoubtedly reflect different familiarity and experience with those advanced techniques that ease the stress of the surgeons skilled in these techniques. It is no surprise that lack of knowledge or experience with a technique leads to skepticism and even hostility, as witnessed in the early days of phacoemulsification for cataract surgery. From our teaching experience, confidence and success with adjustable sutures is only achieved after months of apprenticeship. One should not expect strabismus surgeons who are used to fixed-suture techniques to take the time and effort to become proficient with adjustable sutures - therefore the polarization in attitudes.

It will be difficult to do a randomized clinical trial of adjustable sutures in strabismus surgery because only surgeons well-experienced and comfortable with adjustable suture surgery would be deemed appropriate to participate by the adjustable suture community, and those surgeons are generally too wedded to their fine-tuned adjustable techniques to abandon them for any patient randomized to fixed-suture surgery.

From the patients' point of view, a long-term follow-up study of results and patient satisfaction was conducted in 2013 in Bonn, Germany, of 113 patients after difficult strabismus surgery using adjustable sutures ${ }^{(9)}$. From the questionnaires they completed, $89.4 \%$ had no problems or did not remember the adjustment or tying off procedure. After an average period of 11 years, the satisfaction was high, and reoperation rate was 7\%.

We are firmly committed to our use of adjustable sutures in strabismus surgery, but we do not advocate them for all strabismus surgeons. We encourage those with reservations to take the time and effort to learn the best techniques, by observing those who use them routinely. Better yet is to train with those surgeons; simple observation may not be enough. Adjustable sutures make sense, to us and to our patients. We believe that increasingly better adjustable suture techniques will slowly become the standard of care in the future, probably taking generations rather than years.
\end{abstract}

Submitted for publication: October 6, 2014

Accepted for publication: October 6, 2014

${ }^{1}$ Serviço Oftalmologia Pediátrica e Estrabismo, Instituto de Olhos de Belo Horizonte, Hospital São Geraldo HC, Universidade Federal de Minas Gerais, Belo Horizonte, MG, Brazil.

2 The Krieger Children's Eye Center at the Wilmer Institute, The Johns Hopkins University, Baltimore (MD), USA.
Funding: No specific financial support was available for this study.

Disclosure of potential conflicts of interest: None of the authors have any potential conflicts of interest to disclose.

Corresponding author: Rua Padre Rolim, 541 - 30130090 - Belo Horizonte (MG) - Brazil 


\section{REFERENCES}

1. Jampolsky A. Current techniques of adjustable strabismus surgery. Am J Ophthalmol 1979;88:406-18.

2. Siegel LM, Lozano MJ, Santiago AP. Adjustable and nonadjustable recession and resection techniques. In: Rosenbaum A, Santiago A, editors. Clinical strabismus management: Principles and Surgical Techniques. Philadelphia: W.B. Saunders; 1999. pp. 435-47.

3. Jampolsky A. Strabismus reoperation technique. Trans Am Acad Ophthalmol Otolaryngol 1975;79:704-17.

4. O'Connor R. A new shortening technique. JAMA 1916:67:268-76.

5. Harms H. Ein Vorlagerungsverfahren mit nachtraglicher Dosierungs Möglichkeit. Klin Monatsbl Augenheilkd 1941;104:728.
6. Bielschowsky A. Die neuren Anschauungen über Wesen und Behandlung des Schielens. Med Klin 1907; 335-336

7. Engel JM, Guyton DL, Hunter DG. Adjustable sutures in children. J AAPOS 2014;18: 278-84.

8. Haridas A, Sundaram V. Adjustable versus non-adjustable sutures for strabismus. Cochrane Database of Systematic Reviews 2013, Issue 7. Art. No.: CD004240. DOI: 10.1002/14651858.CD004240.pub3. www.cochrane.org/reviews/en/topics/63.html (accessed 29 aug 2014).

9. Wabbels B, Förster J, Roggenkämper P. Ergebnisse und Patientenzufriedenheit von Schieloperationen mit nachjustierbaren Fäden im Langzeitverlauf. Klin Monbl Augenheilkd 2013;230:983-9. 